\title{
A Report on Resident, Local Migratory and Migratory Water fowl Diversity in Mayurbhanj District, Odisha, Eastern India.
}

\section{Sandeep Ranjan Mishra}

Office of Regional Chief Conservator of Forest \& Field Director, Similipal Tiger Reserve, Mayurbhanj, Asanabani, Odisha, India

\section{Introduction:}

Water birds play a major part in our ecosystem. Besides ecological, this group has various social and economic importance for which species should be conserved on a priority basis. Mayurbhanj is the district of Orissa inhibiting great wildlife diversity, where Similipal National Park is covering the largest area. This is a part of Eastern Ghat which is endowed with rich biodiversity. This study was conducted to know the diversity of waterfowl in this particular area as most of which are seasonal migratory. In this article, I am presenting the list of water fowls time to time observed by me and my staff in the studyarea.

\section{Location under Watched for Migratory Birds:}

TIn the Mayurbhanj district, there are many water bodies, which attract migratory, local migratory and resident birds and also play a vital role in irrigation and pisciculture. We surveyed, a total of 17 water bodies comes under three divisions (Baripada, Karanjia and Rairangpur). We tabulated the species mainly from November 2010 to May 2011. A Direct Visual count method (with binoculars) was employed to list the bird species and where possible an actual count was taken. Where there were a large flock, an estimate (up to the nearest 100 individuals) was made. Each study site was visited for a minimum of three times in three different dates to record variety of water bird species visting to the water bodies. . Birds were identified following Grimmett et. al., (2001) and their status following Ali \& Ripley (2001). The number

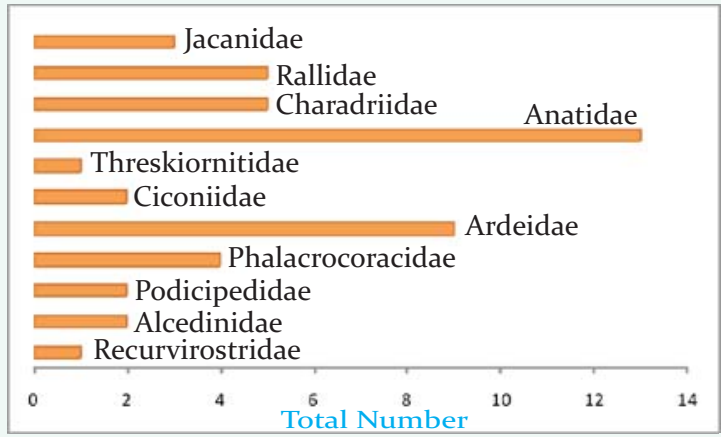

Figure 2: Family-wise number of sighted bird species
Study Area: Mayurbhanj District, Odisha.

Coordinates: $21^{\circ} 16^{\prime}$ to $22^{\circ} 34^{\prime} \mathrm{N}$; $85^{\circ} 40^{\prime}$ to $87^{\circ} 11^{\prime} \mathrm{E}$

Key words: Water bodies, Water birds

of bird species including the number of species individuals observed in each water body has been tabulated in the following table (Table-1).

Table-1: Over view of water bodies with the numbers of species and water birds observed during Study Period.

\begin{tabular}{llcccr}
\hline \# & Water body & $\begin{array}{c}\text { Total } \\
\text { Species } \\
\text { observed }\end{array}$ & $\begin{array}{c}\text { Totalwater } \\
\text { birds } \\
\text { observed }\end{array}$ & $\begin{array}{c}\text { Visit of } \\
\text { Season }\end{array}$ & $\begin{array}{r}\text { Total } \\
\text { days } \\
\text { expent }\end{array}$ \\
\hline 1 & Jambira Reservoir & 17 & 630 & Jan \& Feb & 04 \\
2 & Haladia Reservoir & 21 & 1519 & Jan \& Feb & 04 \\
3 & Kala Dam & 22 & 270 & Nov\& Jan & 03 \\
4 & Badjod Reservoir & 23 & 165 & Dec \& May & 04 \\
5 & Purunapani Pond & 12 & 23 & April \& May & 04 \\
6 & Muktapur pond & 15 & 13 & Jan\& Feb & 03 \\
7 Haladipada pond & 15 & 23 & Feb \& March & 03 \\
8 & Dariha Marsh & 18 & 56 & March \&May & 04 \\
9 & Kalama Pond & 17 & 22 & March & 03 \\
10 Rajabandha Reservoir & 16 & 50 & May & 03 \\
11 & Chhamundia Dam & 18 & 37 & Dec & 03 \\
12 & Salarpada Dam & 17 & 88 & Dec & 03 \\
13 & Rajabandha & 20 & 110 & Nov\& Dec & 03 \\
14 & Kushpada Pond & 19 & 42 & April & 05 \\
15 & Thakuramunda pond & 13 & 36 & April \& May & 03 \\
16 Rani Bandha & 10 & 24 & March & 03 \\
17 Raja Bandha & 22 & 31 & March & 03 \\
\hline
\end{tabular}

OurTabulated Observations:

Total 46 species from 11 families (Figure 1), of waterbirds were recorded from Mayurbhanj district. Out of which, maximum birds are recorded from the Badjod Reservoir (23) and very few birds are sighted in the Rani Bandha (10) species. Species distribution according to a water body is listed in the Table: 1 A checklist is given in Table-2. Migratory birds were found in 18 areas, local migratory birds in 01 area and resident birds in 17 areas. In other areas like the Baldiha dam, Sunei dam, Suleipat dam, Haldia dam and Bankbal dam the submerged vegetation was more luxuriant which attracted a number of migratory birds. The area of Suleipat and Bankbal dam is more in comparison to the other dams covered during our survey. Hence numbers of birds were sighted. 


\section{Future Directions:}

The present bird account may be considered as the baseline information for further studies related to the avifaunal conservation, as such consolidated work on the avifauna of this rich area has not been done earlier. During our survey several instances viz., fishing activities, agricultural activities, human interference have been found. Many of these sites are abode to numerous migratory as well as rare birds discussed in the present report. Proper studies on population dynamics of water birds and the migration pattern migratory bird in these wetlands are highly recommended. All sorts of information which we experienced during the survey were time to time shared with the State forest department and also with NGOs working on wildlife conservations. Thus, some major steps taken have been jointly forest department and NGOs to conserve such hotspot areas.

Table 2:- Checklist of water birds In Mayurbhanj district:

\begin{tabular}{|c|c|c|c|}
\hline & Common Name & Scientific Name & tus \\
\hline & 1. Podicipedidae & & \\
\hline 1. & Great Crested Grebe & Podiceps cristatus & M \\
\hline 2. & $\begin{array}{l}\text { Little Grebe } \\
\text { 2. Phalacrocoracidae }\end{array}$ & Tachybaptus ruficollis & $\mathrm{R}$ \\
\hline 3. & Little Cormorant & Phalacrocorax niger & $\mathrm{R}$ \\
\hline 4. & Great Cormorant & Phalacrocorax carbo & $\mathrm{R}$ \\
\hline 5. & $\begin{array}{l}\text { Indian Cormorant } \\
\text { 3. Ardeidae }\end{array}$ & Phalacrocorax fuscicollis & $\mathrm{R}$ \\
\hline 6. & Indian pond Heron & Ardeola grayii & $\mathrm{R}$ \\
\hline 7. & Cattle Egret & Bubulcus Ibis & $\mathrm{R}$ \\
\hline 8. & Great Egret & Casmerodius albus & $\mathrm{R}$ \\
\hline 9. & Intermediate Egret & Mesophoyx intermedia & $\mathrm{R}$ \\
\hline 10. & Purple Heron & Ardea purpureaR & \\
\hline 11. & Grey heron & Ardea cinerea & $\mathrm{R}$ \\
\hline 12. & Little heron & Butorides striatus & $\mathrm{R}$ \\
\hline 13. & Yellow bittern & Ixobrychus sinensis & $\mathrm{R}$ \\
\hline & $\begin{array}{l}\text { Goliath heron } \\
\text { 4. Ciconiidae }\end{array}$ & Ardea goliath & M \\
\hline 15. & Asian Open bill Stork & Anastomus oscitans & $\mathrm{R}$ \\
\hline 16. & $\begin{array}{l}\text { Lesser adjutant } \\
\text { 5. Threskiornitidae }\end{array}$ & Leptoptilos javanicus & $\mathrm{R}$ \\
\hline & $\begin{array}{l}\text { Black headed ibis } \\
\text { 6. Anatidae }\end{array}$ & \multicolumn{2}{|c|}{ Threskiornis melanocephalus $\mathrm{R}$} \\
\hline 18. & Cotton pygmy-goose & \multicolumn{2}{|c|}{ Nettapus coromandelianus LM } \\
\hline
\end{tabular}

19. Lesser whistling duck

20. Common Pochard

21. Baers Pochard

22. Ruddy shelduck

23. Common shelduck

24. Mallard

25. Northern Pintail

26. Northern shoveller

27. Ferruginous Pochard

28. Tufted duck

29. Eurasian Wigeon

30. Gadwall

7. Rallidae

31. Common Coot

32. White breasted waterhen Amaurornis phoenicurus

33. Ruddy breasted Crake

34. Common moorhen

35. Purple swamphen

8. Charadriidae

36. Common Sandpiper

37. Little ringed Plover

38. Marsh Sandpiper

39. Green sandpiper

40. Red wattled lapwing

9. Jacanidae

41. Bronze-winged jacana

42. Pheasant-tailed jacana

43. Great thick knee

10. Recurvirostridae

44. Black winged stilt

11. Alcedinidae

45. Common Kingf isher

46. White-throated kingfisher

Dendrocygna javanica

$\mathrm{R}$

Aythya ferina

Aythya baeri

Tadorna ferruginea

Tadorna tadorna

Anas platyrhynchos

Anas acuta

Anas clypeata

Aythya nyroca

Aythya fuligula

Anas Penelope

Anas strepera

Fulica atra

Porzana fusca

Gallinula chloropus

Porphyrio porphyrio

Actitis hypoleucos

Charadrius dubius

Tringa Stagnatilis

Tringa ochropus

Vanellus indicus

Metopidius indicus

Hydrophasianus chirurgus

Esacus recurvirostris

Himantopus himantopus

Note: R-(Resident) LM- (local Migratory) M- (Migratory)

Acknowledgements:

I would like to thanks Orissa forest department for the kind permission to undertake this study. Thanks are also due for the Range officers and field

staffs of all the three division for theirvaluable co-operation.

\section{References:}

Ali, S. \& Ripley, S.D. (2001): Hand book of Birds of India and Pakistan (Vol. 1 \& 2). Oxford University Press, New Delhi

Grimmett, R., Inskipp, C. \& Inskipp, T. (2001): Pocket guide to the Birds of Indian Subcontinent. Oxford University Press, and New York.

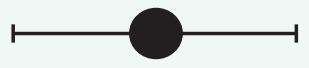

